\title{
Cavas históricas de ouro do Jaraguá: o que resta para se preservar?
}

\section{Celso Dal Ré Carneiro ${ }^{1}$, Luiz Fernando dos Santos ${ }^{2}$ \& José Reynaldo Bastos da Silva ${ }^{3}$}

\begin{abstract}
Resumo As áreas de ocorrência das "Cavas de Ouro Históricas do Jaraguá", nos bairros Morro Doce e Jardim Britânia, município de São Paulo (SP), foram levantadas para apoiar medidas de preservação. As escavações, da época colonial, são ocupadas por densa vegetação; os taludes abruptos laterais delimitam fundos planos e estreitos. O traço sinuoso dos restos, orientado segundo N40-50W, acompanha zona de transição entre pacotes de rochas neoproterozoicas: a SW ocorrem metapelitos e metapsamitos e, a NE, rochas cálciosilicáticas e anfibolitos. As cavas são controladas por estruturas formadas em três fases de deformação. A expansão urbana e as rodovias, nas últimas três décadas, avançaram vigorosamente sobre os vestígios, porém ainda restam quatro, denominados: (I) Faldas do Morro do Quebra-Pé; (II) Jardim Britânia; (III) Morro Doce e (IV) Parque Nova Anhangüera. Um quinto local foi desfigurado por terraplenagem. A Cava do Jardim Britânia, parcialmente descaracterizada, sofreu aterramento parcial para construção de escola pública, mas ainda se pode propor medidas de proteção. Uma vez que as cavas estão bem preservadas, pode-se recomendar às autoridades que: (1) avaliem a alternativa do tombamento imediato das áreas; (2) desenvolvam programas para implantar sítios de divulgação científica ou um centro educacional integrado com exposição de amostras de rochas, minérios e minerais da região; (3) apoiem o interesse de alguns proprietários de preservar a área denominada "Cava Morro Doce"; (4) estimulem iniciativas de uso educativo das cavas, mediante produção de roteiros de visita aos sítios históricos. As alternativas ajudarão a recuperar parte da história da mineração paulista.
\end{abstract}

Palavras-chave: Geologia, Grupo São Roque, mineração, ouro, patrimônio histórico.

\begin{abstract}
The Historical "Jaraguá Gold Caves": what remains to be preserved? The Historical "Jaraguá Gold Caves" are vestiges of excavations in weathered rock, dating back to the Brazilian colonial times, situated NW of Jaraguá peak, in the São Paulo municipality (SP). The areas were investigated to support historical preservation innitiatives. The excavations have lateral steep slopes and a narrow flat bottom zone, occupied by dense vegetation. The trace of the excavations is sinuous, trending N40-50W, in accordance to a transition zone of Neoproterozoic rocks: metapelites and metapsamites by the SW side and calc-silicate rocks and amphybolites at NE. The structural control results from three successive deformation phases. Urban expansion and road construction, during the last 30 years, have strongly impacted the areas: (I) Base of Quebra-Pé hill; (II) Jardim Britânia; (III) Morro Doce; (IV) Nova Anhangüera Park. A $5^{\text {th }}$ site was disfigured by earthworks. The Jardim Britânia area is partly discharacterized by earthfills; this however does not impede further protection actions. This framework allows to recommend authorities: (1) to permit immediate preservation of these areas; (2) to develop programs to build an integrated site for scientific diffusion or an educational center for exhibition of rocks, ores and mineral samples; (3) to support the interest of some owners to preserve the area called "Morro Doce", (4) to put forward a few proposals for educational use of the excavations, by production of field guides on the historic sites. The alternatives will help keeping alive the memory of mining in the São Paulo State.
\end{abstract}

Keywords: Geology, São Roque Group, mining, gold, heritage conservation.

INTRODUÇÃO Investigações recentes na área de ocorrência das "Cavas de Ouro Históricas do Jaraguá" atualizaram informações sobre vestígios de lavras de ouro, que remontam aos tempos do Brasil Colônia (Carneiro 2002). A pesquisa buscou subsidiar o eventual tombamento parcial ou total das escavações, situadas na região NW do município de São Paulo (Fig. 1), por determinação da Procuradoria da República no Estado de São Paulo, vinculada ao Ministério Público Federal. A extração de ouro na região do Jaraguá, por Afonso Sardinha e seu irmão, parece ter sido muito próspera no período entre 1588 e 1597 (Knecht 1950, p. 25). Em 1560 Brás Cubas cita a qualidade do ouro de São Paulo (Martins et al. 1989). As primeiras investigações científicas a respeito da geologia regional remontam ao início do século XIX. O estudo publicado em

1 - Universidade Estadual de Campinas, Instituto de Geociências, Departamento de Geociências Aplicadas ao Ensino, Campinas (SP), Brasil. E-mail: cedrec@ige.unicamp.br

2 - Geólogo da Prefeitura de São Paulo, Subprefeitura de Perus (SP), Brasil. E-mail: 1fernandosantos@prefeitura.sp.gov.br

3 - Doutor pelo IGCE/UNESP, Rio Claro (SP) e consultor autônomo. E-mail: reynaldo.bastos@hotmail.com 


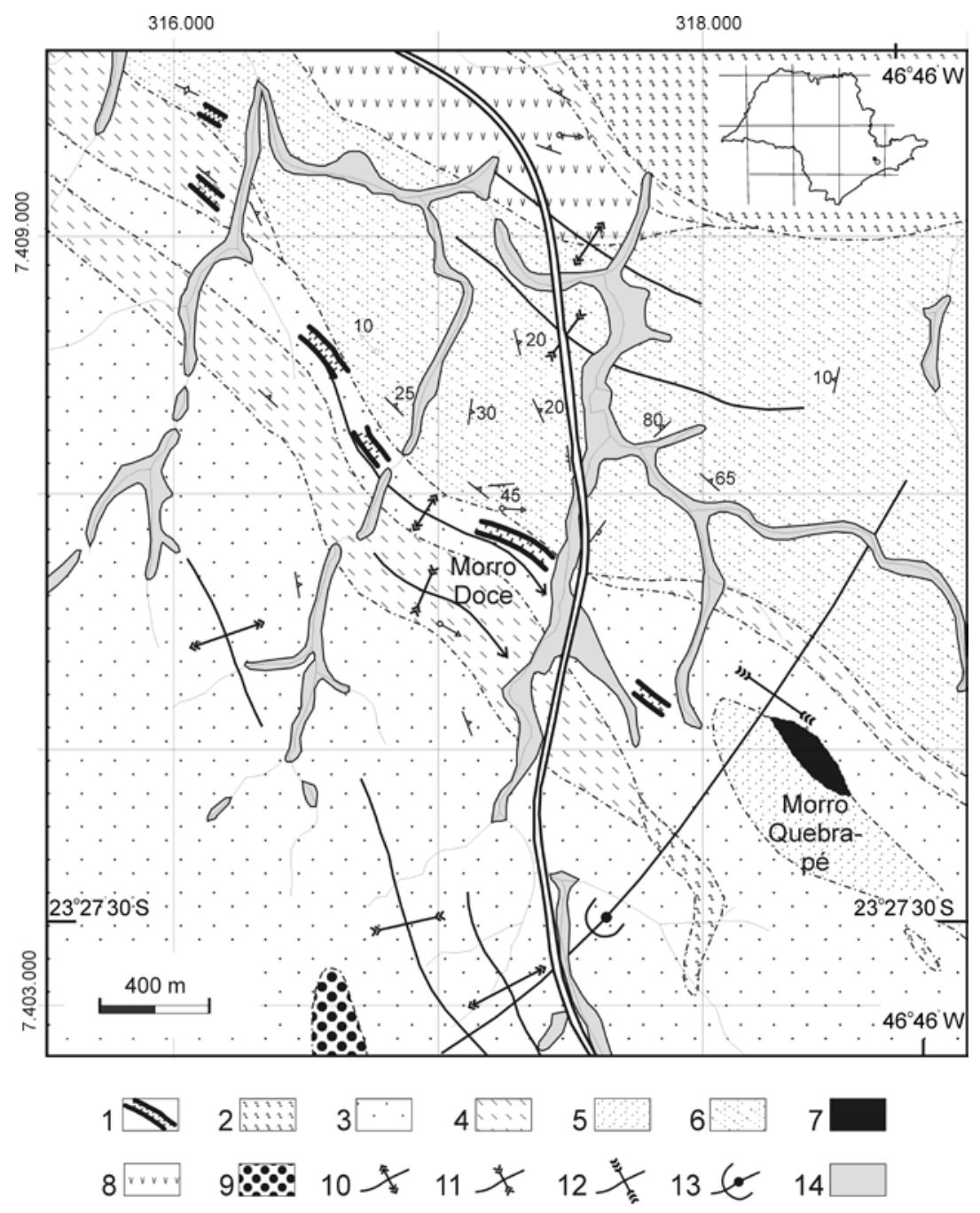

Figura 1 - Cavas da região do Morro Doce, NW de São Paulo. (1) Cavas conhecidas. (2) a (9) Unidades metamórficas neoproterozóicas: (2) xistos, (3) metarenitos, (4) filitos vermelhos, (5) quartzitos, (6) rochas cálcio-silicáticas, (7) Anfibolitos, (8) Anfibolitos bandados e metatufitos, (9) Metaconglomerados. Convenções geológicas: (10) Antiforma F2, (11) Sinforma F2, (12) Sinforma F3, (13) Dobra neutra F3, (14) Aluviões quaternários.

1820 pelos irmãos José Bonifácio de Andrada e Silva e Martim Francisco Ribeiro de Andrada, "Viagem Mineralógica pela Província de São Paulo no ano de 1805", refere-se às lavras de ouro de Quebra-Pedra, Santa Fé, Ribeirão das Samambaias e Itaim, no Município de São Paulo, como "lavras antigas", pois os autores as encontraram em estado de completo abandono, sendo informados de que isso já havia acontecido muitos anos antes da visita. A criação da Comissão Geográfica e Geológica da Província de São Paulo em 1886 deu início à sistematização de levantamentos cartográficos e reconhecimentos geológicos. Knecht (1950) apresenta mapa detalhado da localização de lavras esgotadas de bens metálicos nas vizinhanças da Capital paulista.

$\mathrm{O}$ conhecimento geológico do Estado de São Paulo avançou no século XX, tanto no inventário de informações sobre patrimônio mineral (IPT 1981), quanto na caracterização de rochas, geomorfologia e evolução tectônica. A partir dos anos 1990, por falta de incentivos, interromperam-se os estudos sistemáticos dessas e outras ocorrências (Carneiro \& Hermann 1994a, 1994b).

O objetivo central do presente artigo é caracterizar o estado de conservação e avaliar alternativas para recuperação ou tombamento. $\mathrm{O}$ método de trabalho (Carneiro et al. 2010) envolveu trabalhos de campo para coleta de dados georreferenciados de limites e vias de acesso das ocorrências (Carneiro 2002). Os objetivos específicos são: (a) sugerir alternativas de aproveitamento das cavas, uma vez recuperadas / protegidas / tombadas, como sítios de divulgação científica à sociedade ou centros de atividades educacionais; (b) acentuar a função do profissional geólogo nessa linha de estudo, e (c) ilustrar o papel essencial da divulgação 
científica para preservação de sítios situados em zonas metropolitanas sujeitas a expansão urbana acelerada.

A abordagem acompanha as modernas iniciativas de geoconservação e tendências de pesquisa sobre patrimonio geológico. Duas etapas antecedem o estabelecimento de qualquer política eficaz de geoconservação: o inventário do patrimônio e a formulação de leis. Ambas fazem parte das quatro etapas previstas nas práticas usuais de geoconservação: (1) inventário; (2) legislação; (3) geoconservação; (4) geodivulgação, didática e geoturismo. Carcavilla et al. (2009) indicam que, no caso da Espanha, a abordagem geológica pode dificultar a compatibilização entre um inventário abrangente e as políticas de geoconservação. O maior desafio é sobretudo mudar a ênfase dos trabalhos: da visão estritamente exploratória dos recursos para um olhar dedicado à preservação de sítios de grande valor geológico. A situação brasileira não é muito distinta; não obstante, iniciativas de geoconservação tornam-se cada vez mais comuns e frequentes. Este artigo descreve resultados de inventário detalhado das antigas cavas e discute as perspectivas do estudo para estabelecer regras de proteção à história da mineração em São Paulo.

GEOLOGIA E HISTÓRIA DA MINERAÇÃO As lavras do Jaraguá, esgotadas no século XVII, são também conhecidas como "Cavas de Ouro do Morro Doce", tendo sido abertas em rochas do grupo São Roque (Neoproterozoico). As unidades metassedimentares incluem (Fig. 1): metarenitos impuros e metarcósios; filitos; quartzitos; rochas cálcio-silicáticas e diversos tipos de xistos (Carneiro 1983). Anfibolitos e metatufos ocorrem como intercalações nos pacotes metassedimentares (Coutinho 1980). O conjunto é atravessado por granitos tardi-tectônicos, além de granitos, aplitos e pegmatitos pós-tectônicos (Hasui et al. 1969).

Os pacotes foram intensamente dobrados e metamorfizados por ocasião das colisões de placas que culminaram na formação do paleocontinente Gondwana (Heilbron et al. 2004). Em Santana do Parnaíba, Tas- sinari et al. (2001) obtiveram datações de rochas metavulcânicas máficas que vinculam as rochas do Grupo São Roque ao Ciclo Brasiliano (Almeida et al. 2000). As idades U-Pb de $628 \pm 9$ Ma foram atribuídas à cristalização de magmas formadores de "pillow-lavas" (Figueiredo et al. 1982), que constituem complexos ofiolíticos (Tassinari 2010).

Geologia local A distribuição geográfica e o sinuoso traçado das cavas do Jaraguá (Fig. 1) refletem padrão singular, que por sua vez está vinculado a pelo menos três controles litológico-estruturais: (a) orientação geral dos corpos segundo NW; (b) arranjos geométricos resultantes do complexo padrão de dobramento e redobramento regionais; (c) existência de ampla zona transicional entre pacotes neoproterozoicos, representados a SW por metarenitos, quartzitos, filitos e xistos e, a $\mathrm{NE}$, rochas cálcio-silicáticas e anfibolitos.

As cavas de ouro são controladas por estruturas ligadas a três fases sucessivas de deformação, reconhecidas por Carneiro (1983) e referidas por Carneiro et al. (1985). A composição geoquímica das unidades rochosas e suas relações com os fluidos percolantes devem ter influenciado a mobilização de ouro e acumulação na forma de veios. O ouro foi liberado pela alteração intempérica de minerais como pirita. Análise de amostra coletada em veio de quartzo revelou teor de $20 \mathrm{ppm}$ de Au livre e evidenciou que a liberação do metal deve-se à alteração de pirita em limonita (Carneiro 1983).

DESCRIÇÃO Na região entre o Jaraguá (Fig. 2a) e o Morro Doce, os vestígios de atividades de mineração de ouro são sobretudo formas lineares, com paredes muito abruptas, implantadas em rocha decomposta. Os mapas disponíveis foram produzidos nos anos 1980 (Carneiro 1983). Apesar do grau de alteração das rochas, é possível observar estruturas, como foliações, dobras, pequenas falhas e juntas. Conforme ver-se-á adiante, em pelo menos uma das cavas a urbanização insiste em descaracterizar o valioso patrimônio históri-
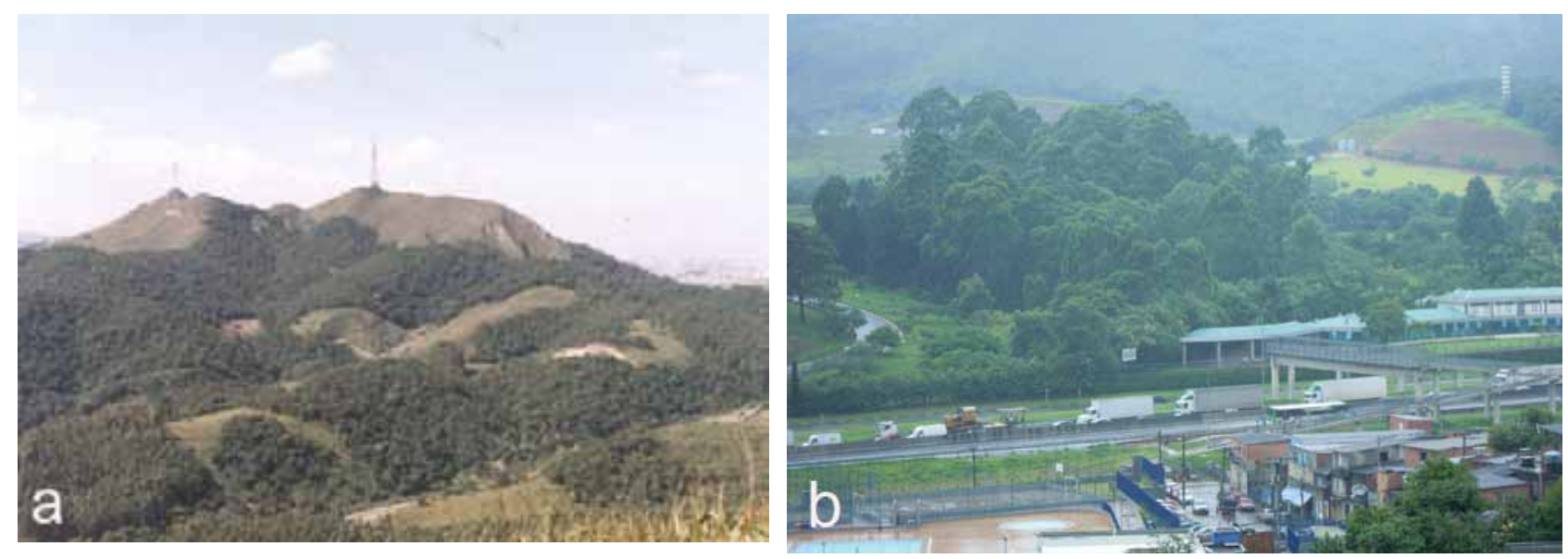

Figura 2 - O Parque Estadual do Jaraguá circunda o pico homônimo (a); foto feita a partir do Morro Doce para SE, em 1982. A Cava I situa-se em meio a mata de eucaliptos, às margens da Rodovia Anhangüera (b). 
co (Carneiro 1996). As demais se acham razoavelmente bem preservadas. As cavas da região do Morro Doce foram discriminadas por Carneiro et al. (2010) da seguinte forma:

(I) Faldas do Morro do Quebra-Pé.

(II) Jardim Britânia.

(III) Morro Doce.

(IV) Parque Nova Anhangüera.

(V) Restos não-identificados naquela época.

Cava I: Faldas do Morro do Quebra-Pé Pequena mancha de eucaliptos separa as áreas edificadas de dois cemitérios adjacentes: o Cemitério Gethsêmani Anhanguera e o Cemitério-Parque Jaraguá. A Cava I está parcialmente encoberta pelo arvoredo, que lhe oferece certa proteção. As paredes em rocha decomposta não ultrapassam $4 \mathrm{~m}$ de altura em um dos lados. No local, Carneiro (1983) recolheu amostras de veios de quartzo. O teor de um desses veios corresponde a minério, com $20 \mathrm{ppm}$ de $\mathrm{Au}$ livre, na forma de concentrações submicroscópicas.

Cava II: Jardim Britânia A Cava II, a mais extensa do conjunto, foi descrita por Carneiro (2002) como "cava principal". No alto da elevação, situa-se a Escola Municipal de Ensino Fundamental (EMEF) do Jardim Britânia, visível desde a Rodovia Anhangüera (Fig. 3). O conjunto de fotografias das figuras $4 \mathrm{a}$ e $4 \mathrm{~b}$ ilustra o avanço da ocupação entre 1982 e 1993. O aspecto em forma de "V", o fundo estreito e chato, e as paredes abruptas de aproximadamente $20 \mathrm{~m}$ de altura, coincidem com os da imagem da clássica publicação de Knecht (1950).

Theodoro Knecht, estudioso dos minérios paulistas, publicou em 1950 uma foto da escavação maior (Knecht 1950, p.26), em ângulo igual ao da cena que se tem hoje desde a Via Anhangüera, descrevendo-a como uma "escavação antiga" de ouro. A expressão, aliás, não lhe pertence. As ruínas de cavas a céu aberto foram consideradas antigas pelo mineralogista José Bonifácio de Andrada e Silva, por volta de 1822, em visita à Província de São Paulo. Na Capitania de São Vicente, essas extrações pioneiras anunciaram nossa vocação mineira - no final do século XVI - junto com as de Paranaguá (Carneiro 2002).

No início dos anos 1980, a área despovoada ao redor da Cava II ficava em zona rural (Fig. 4a). Para a construção da unidade escolar, na década seguinte, o governo estadual implantou aterro para acomodar parte do terreno e dar acesso à população da parte $\mathrm{N}$ do bairro (lado direito da Fig. 4b), pois as paredes da cava formavam abismo difícil de ser atravessado a pé. A solução, além de descaracterizar parcialmente os vestígios, criou ali pequena área de risco, porque os muros e paredes são periodicamente afetados por trincas e rachaduras, associadas a prováveis movimentações do aterro malcompactado. Hoje, moradores fazem lançamento irregular, no local, de restos de construção civil (entulho), lixo e solos inaproveitáveis (Fig. 4d).

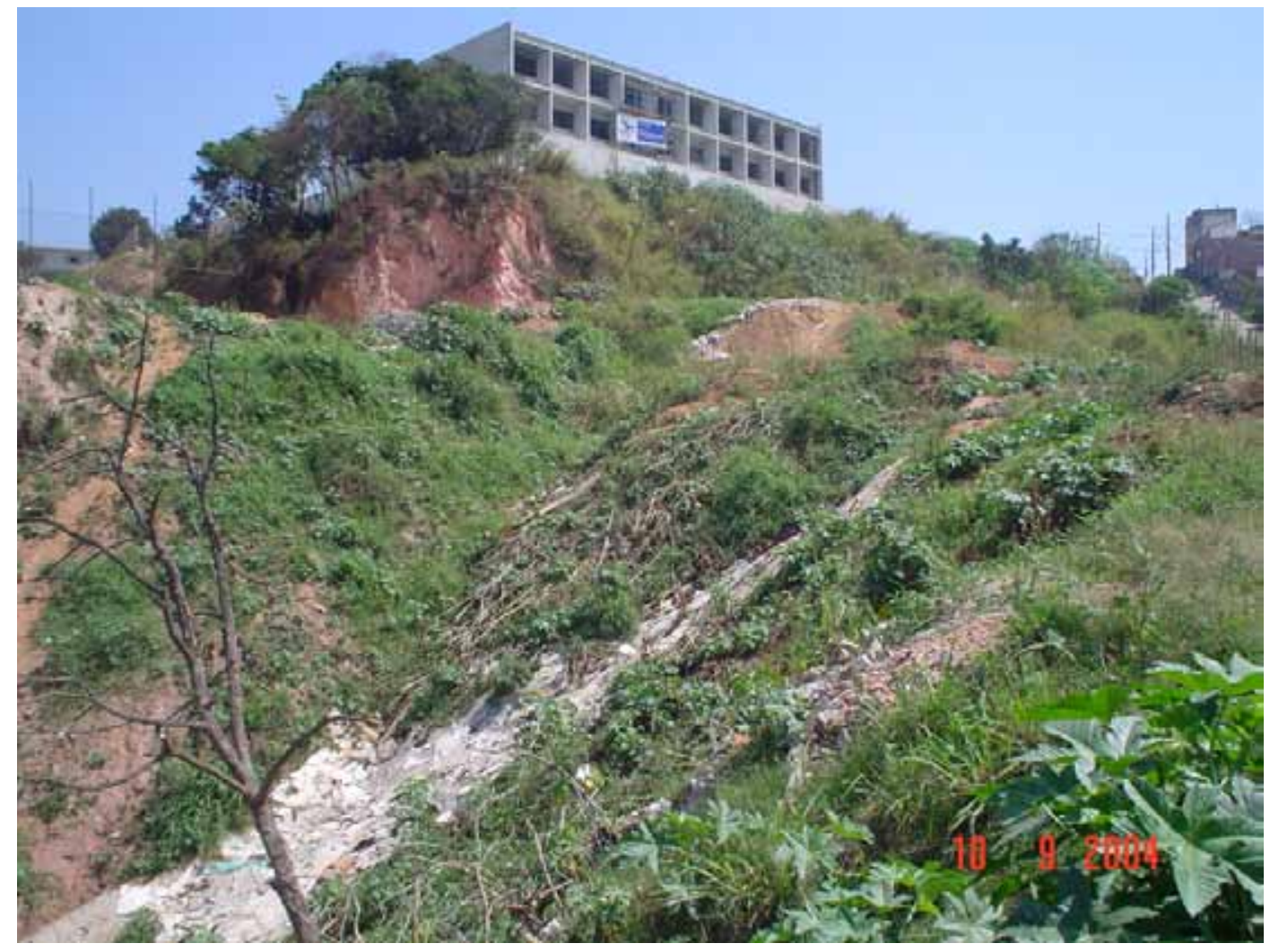

Figura 3 - Aspecto geral da Cava do Jardim Britânia, em 2004. Taludes expostos à ação das intempéries e grande quantidade de material irregularmente depositado. A antiga superficie do terreno foi soterrada. 

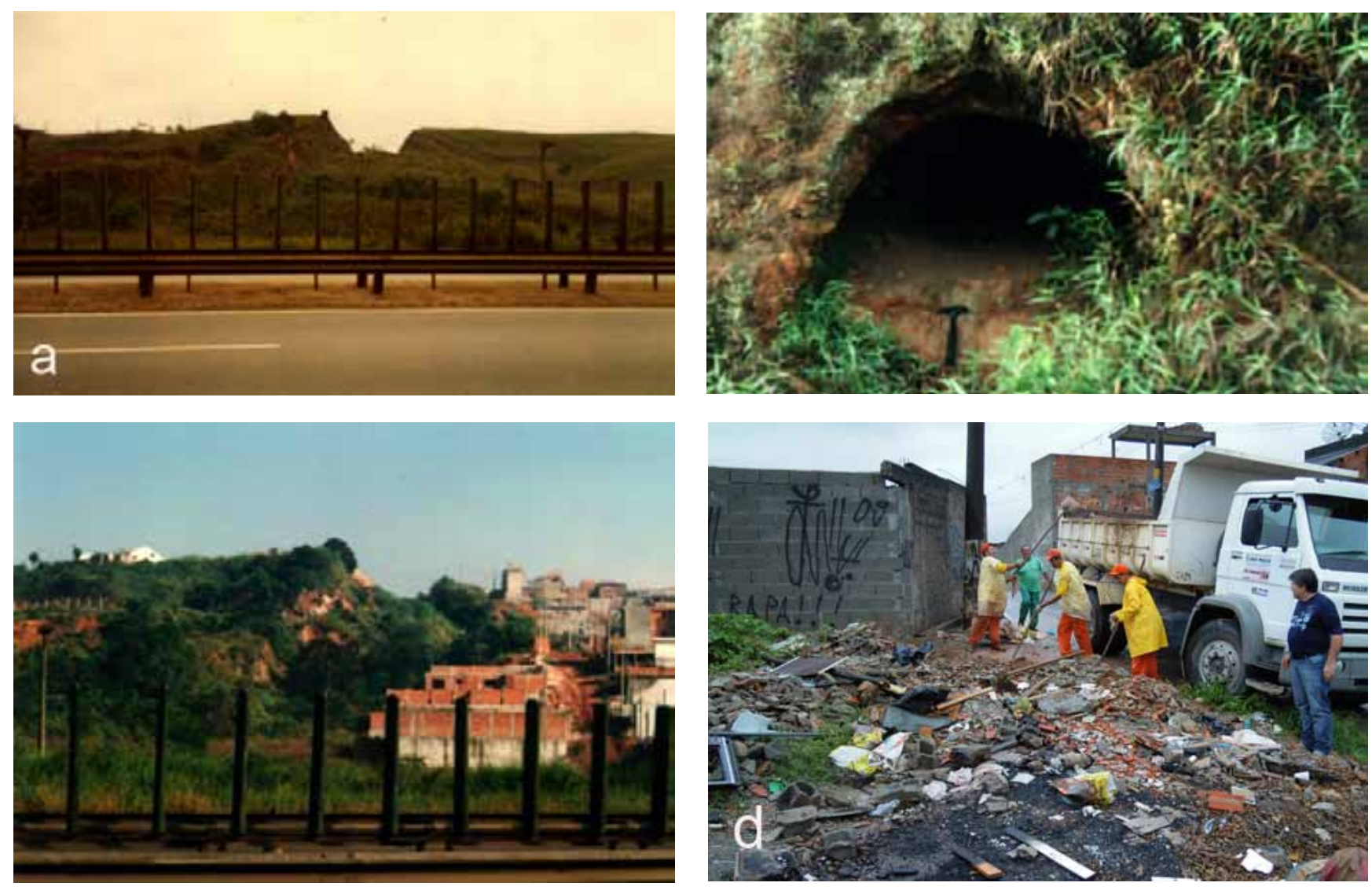

Figura 4 - Diferentes aspectos da mesma Cava II, em 1982 (a); 1993 (b). A faixa central de terras pertence ao município. Em (c) observa-se resto de galeria de pesquisa que desapareceu em 2007, devido à ampliação da Rodovia Anhangüera. É comum o descarte de lixo, restos de entulho (d) e outros materiais pela população.

Na base da parte central da Cava II, Carneiro (1983) identificou longa galeria de pesquisa suavemente inclinada para NW, escavada em filitos, xistos e metarenitos decompostos. Na extremidade da galeria havia poço vertical (shaft) que acabou sendo recoberto pelo aterro, que escondeu qualquer vestígio tanto da galeria como do poço. O formato da abóbada, em curva, era similar ao da galeria da figura $4 \mathrm{c}$, distante cerca de $400 \mathrm{~m}$ da cava, a NE, em corte da Rodovia Anhangüera. A fotografia $4 c$ é de um dos três remanescentes de galerias de pesquisa existentes até setembro de 2007. Obras de implantação das pistas marginais da rodovia destruíram por completo o que ainda restara das feições.

O local onde se situa a Cava II sofreu aterramento e obras que descaracterizaram parte da feição. Atualmente a escola está sob administração municipal, sendo denominada EMEF do Jardim Britânia. Para efeito de delimitação, a cava estende-se de SE para NW entre a faixa de domínio da Rodovia Anhangüera, junto à margem $\mathrm{W}$ do córrego Santa Fé, até a Rua Paraná, ou José Xavier da Costa, no Jardim Britânia. Muros dos quintais de casas da rua Serra das Emburanas, antes denominada rua Mato Grosso, e um trecho dessa mesma rua (sem casas), percorrem toda a borda setentrional da cava. O limite meridional é feito por áreas controladas pelo Estado, particularmente dois centros de esporte e lazer, conhecidos como CEU (Centro Educacional Unificado) Anhangüera e CDC (Centro Desportivo da Cidade) Cel. José Gladiador. Escolas, como a do Jardim Britânia, podem favorecer o desenvolvimento de centro educacional que exploraria esta e as demais ocorrências analisadas, como forma de aproveitar espaços públicos e privados.

Uma iniciativa de preservação das cavas acabou sendo premiada em concurso de abrangência nacional que busca valorizar o "patrimônio histórico, natural, artístico e afetivo brasileiros" (Projeto Tesouros do Brasil 2005). Participaram do certame grupos de, no mínimo, cinco alunos, sendo obrigatória a presença de pelo menos um professor responsável pelo trabalho de cada grupo. Era livre o número de grupos de alunos e não se estabelecera limite para número de grupos por professor. Apenas quatro grupos receberam, nos anos de 2004 e 2005, o prêmio máximo, porém cerca de 100 projetos foram incluídos nos livros editados pela empresa patrocinadora.

Sob coordenação do Prof. Marcello M. Jorge, da EMEF do Jardim Britânia, alunos e professores produziram proposta de museu, contemplada na edição de 2004 desse concurso. O item "Escavações de ouro do Morro Doce" encontra-se nas páginas 28 e 29 da obra, cujo arquivo digital pode ser baixado do sítio http:// 
www.tesourosdobrasil.com.br/, junto com o "guia de bens culturais" que consolida "os 667 projetos enviados para o concurso Tesouros do Brasil”.

Cava III: Morro Doce A situação das Cavas III e IV é altamente positiva. Os locais estão bem preservados, sem indícios de devastação ou invasões. A "Cava III Morro Doce" situa-se parcialmente em terras privadas e parcialmente em terras do município (Fig. 5), existindo preocupação explícita de proprietários da parte particular em preservar a área.

A cava ainda mantém o característico aspecto em forma de "V", o fundo estreito e chato, e paredes abruptas. Predominam filitos e metarenitos decompostos avermelhados, além de metassiltitos róseos e, subordinadamente, rochas cálcio-silicáticas. Reconhecem-se diversas ocorrências de veios de quartzo. As dimensões das paredes e a largura do fundo foram estimadas com certa precisão: a altura dos cortes é de aproximadamen-
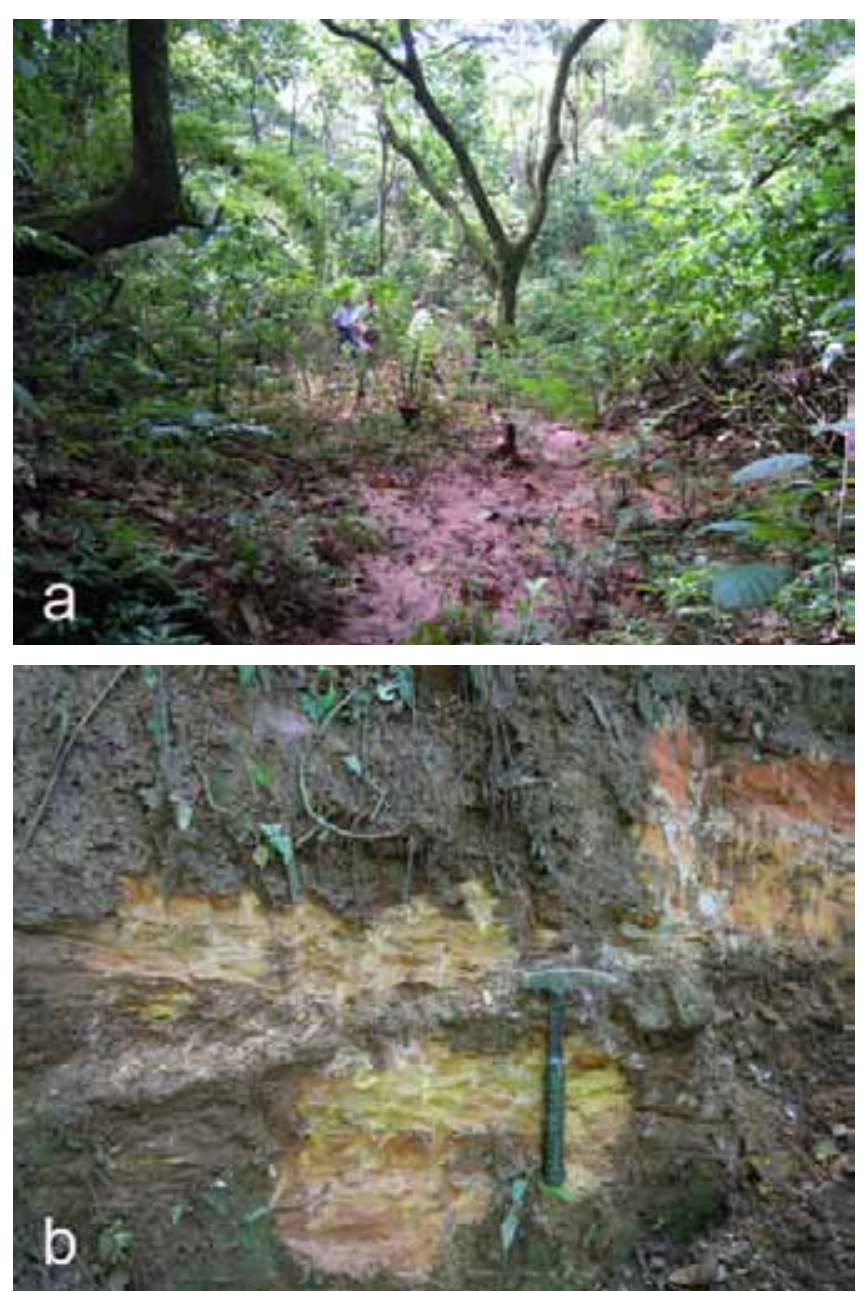

Figura 5 - Estado atual da cava de ouro do Morro Doce (Cava III). Os limites são taludes inclinados, com cerca de 25 a $30 \mathrm{~m}$ de altura. O fundo do terreno é recoberto por sedimentos areno-argilosos e mata nativa em toda a extensão da cava. O acesso é feito por trecho inclinado de encosta (a); em (b) observa-se rocha metarenitica intemperizada da parede NE da cava. te $24 \mathrm{~m}$ e a largura, cerca de $15 \mathrm{~m}$. Quanto ao comprimento da cava, estimaram-se cerca de 100 a $150 \mathrm{~m}$ : os vestígios são visíveis desde o córrego que é afluente do córrego Santa Fé, até as cabeceiras do pequeno vale formado pela cava.

Cava IV: Parque Nova Anhangüera No final da rua Profa. Maria Aparecida Nigro Gava, no bairro Vila Nova, também conhecido como Parque Nova Anhangüera ou Jardim Britânia, encontra-se o portão de acesso para a Empresa Stemag Engenharia e Construções Ltda. O pátio dá acesso à extensa área florestada que protege a Cava IV, cujas dimensões foram avaliadas de modo incompleto, pela falta de autorizações de ingresso na parte central da mata. A altura dos cortes é estimada em cerca de 10 a $15 \mathrm{~m}$, e a largura medida é superior a $15 \mathrm{~m}$ na base da cava.

Cava V: Restos não-identificados As cavas mais setentrionais referidas por Carneiro (2002), que constam da figura 2, não podem mais ser localizadas em campo. Pela imagem do Google Earth (Fig. 6), observa-se que os restos foram destruídos por terraplenagem, ao se implantar depósitos ou galpões industriais.

ESTADO DE CONSERVAÇÃO DAS CAVAS O conjunto conhecido é importante testemunho da mineração colonial (Fig. 6). As escavações são facilmente identificadas pelo traçado linear típico e manchas de vegetação que, de certa forma, as circunscreve e protege. Os fatores que facilitam o mapeamento são: o alinhamento aproximado, na direção N40-50W (Fig. 6), e o fato de se

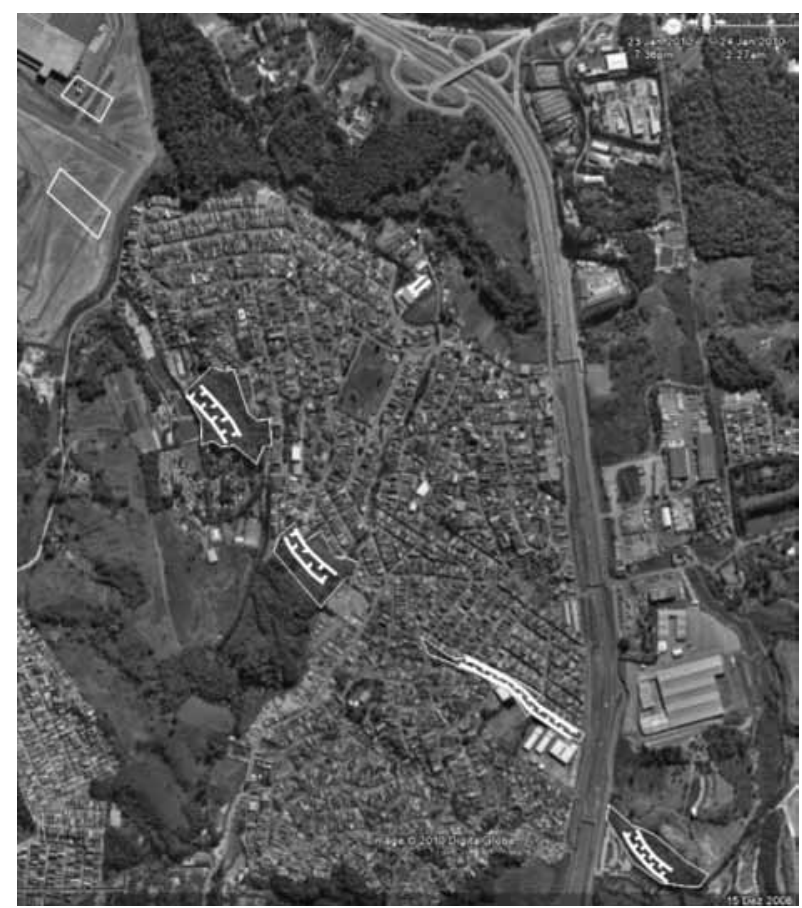

Figura 6 - Localização atual das cavas de ouro (Cavas I a V); pormenores estão nas figuras individuais 8 a 11 . 
vincularem à zona de contato de grandes grupos de rocha.

Quanto ao estado de conservação, as cavas encontram-se em situação de grande vulnerabilidade, em virtude da rápida expamsão urbana; é preciso distinguir cavas localizadas em terras públicas e privadas. Durante quatro séculos, as cavas situadas em terrenos públicos resistiram ao processo natural de erosão e assoreamento e às ações humanas de desflorestamento e invasão de terras. Não ficaram porém imunes aos governos dos últimos 30 anos. A atuação mais decisiva para destruição desse patrimônio foi o próprio Estado, que aprovou a execução de, ou executou diretamente, obras que descaracterizaram parte das feições. Resultou desse processo que a Cava II fosse parcialmente desfigurada, devido a aterramento para uma construção escolar.

A sensação de abandono que os locais oferecem torna urgente a ação protetora pelo Poder Público. As propriedades situadas em terras privadas foram relativamente bem protegidas, com exceção da Cava V (Fig. 6). Apesar da legislação ambiental restritiva, as cavas continuarão ameaçadas pela expansão urbana nas próximas décadas.

Delimitação Embora a vegetação oculte parte das feições diagnósticas, como taludes e áreas rebaixadas, é possível definir limites e identificar os titulares de áreas. O exemplo de delimitação da Cava IV - Parque Nova Anhangüera (Fig. 7), ilustra o procedimento geral, baseado no cadastro municipal de propriedades. A situação de cada remanescente de escavação em imagem Google Earh encontra-se nas figuras 8, 9,10 e 11.

PROPOSTAS DE AÇÃO PARA APROVEITAMENTO EDUCATIVO Preservar a memória técnica e a cultura integra as raízes do processo de formação e consolidação da identidade de um povo. Nos últimos anos têm aparecido numerosas iniciativas, com destaque para pessoas desligadas do campo técnico específico da geoconservação, além de especialistas e autoridades políticas ou profissionais. Um exemplo são os parques temáticos de Salto e Itu (Almeida \& Carneiro 1995), inaugurados em 1995 pelas prefeituras municipais das cidades, com apoio de órgãos do governo estadual, que acolhem centenas a milhares de visitantes de diversas partes do Estado. Nova consciência ambiental formar-se-á a partir dessas ações positivas, o que pode inverter a tendência atual de abandono de outras áreas em condição parecida.

Em linha complementar tem-se publicações que resgatam e atualizam a produção de eminentes estudiosos. Um exemplo é o livro que homenageou o principal cientista brasileiro da área de geologia, Prof. Dr. Fernando Flávio Marques de Almeida (Mantesso Neto et al. 2004). Nessa linha, sugerem-se estudos sobre história da mineração no Brasil que resgatem a obra de personalidades como o mineralogista José Bonifácio de Andrada e Silva e outros.

Tendo em vista esse amplo leque de alternativas, é possível explorar as cavas para finalidades educativas, como:

1- Implantação de centro de história da mineração paulista.

2- Montagem de exposição permanente de rochas, minérios e minerais da região do Jaraguá e arredores.

3- Elaboração de roteiros de visita aos sítios históricos.

Centro de história da mineração paulista Um centro de memória abrangendo a história da mineração paulista será espaço de capacitação de monitores e divulgação científica. O centro estimulará o envolvimen-

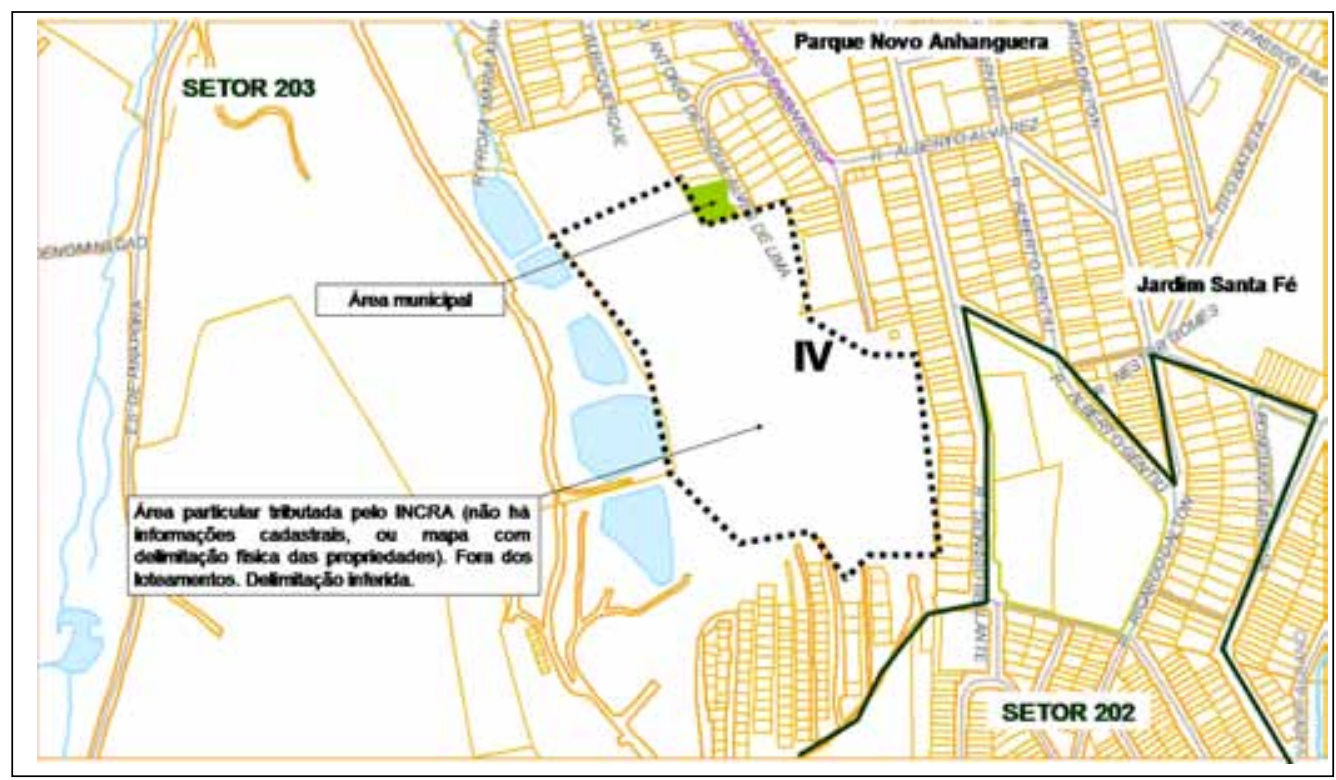

Figura 7 - Cava IV: A área da Cava IV é uma propriedade particular, tributada pelo INCRA. Talvez os proprietários jamais tenham sido alertados para a existência do sitio histórico. 


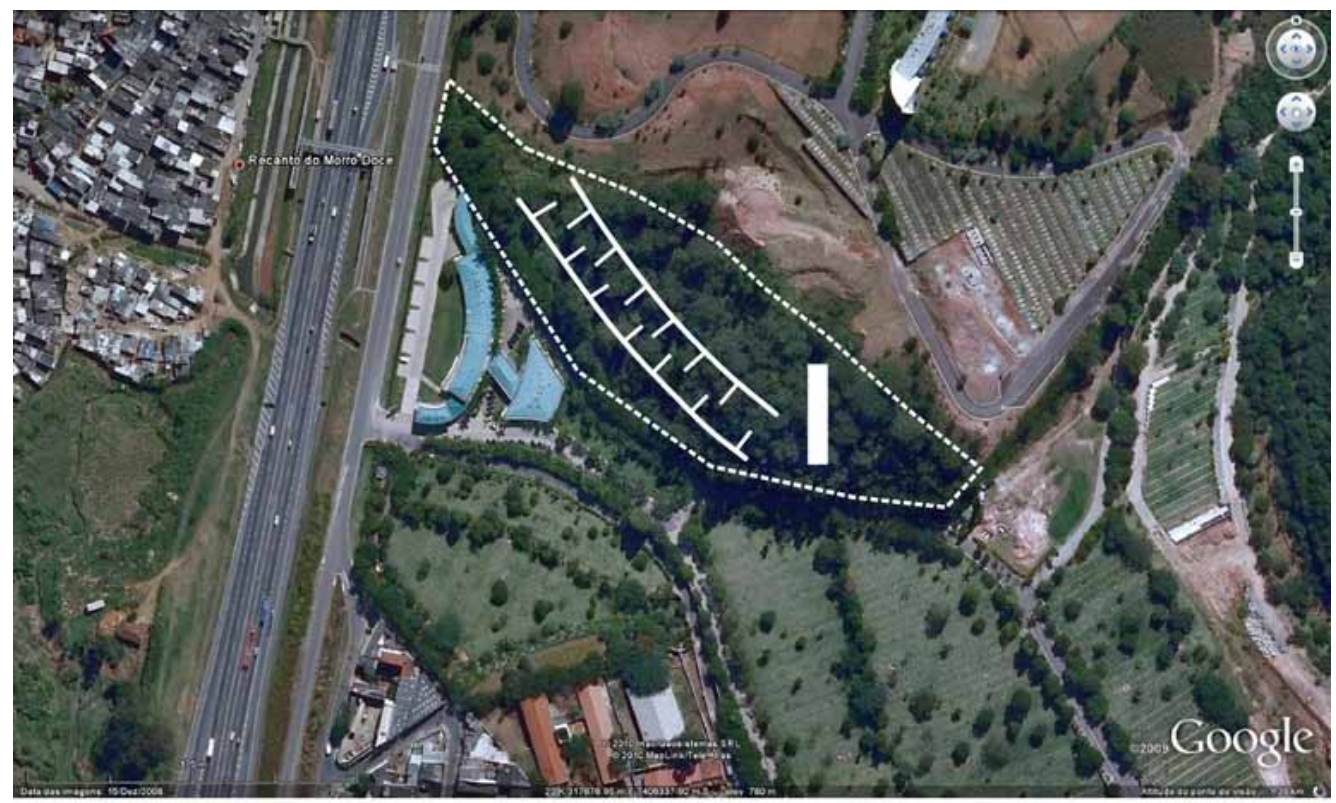

$$
1 \gg
$$

Figura 8 - Situação da Cava I - Faldas do Morro do Quebra-Pé, em imagem Google Earh. (1) Cava; (2) Proposta de área para medidas de preservação ou tombamento.

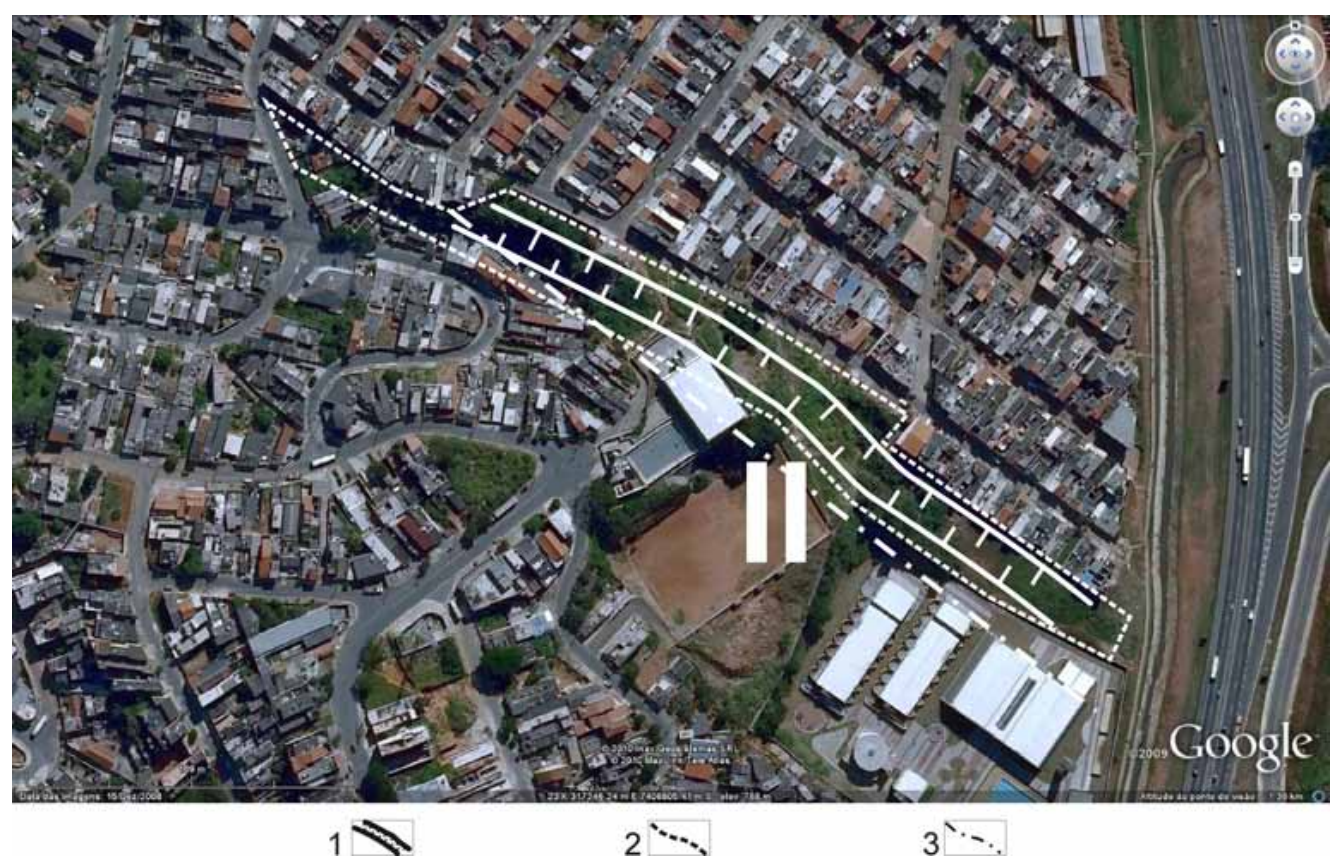

Figura 9 - Situação da Cava II - Jardim Britânia, em imagem Google Earh. (1) Cava; (2) Proposta de área para medidas de preservação ou tombamento; (3) Limite entre áreas públicas e privadas.

to de escolas, moradores e jovens da região, ao reunir materiais e documentos e formar exposição adaptada ao contexto local. Muitas amostras poderão ser obtidas com rapidez, por doação de especialistas, estudiosos e colecionadores particulares. A exposição abrigará mapas, gravuras, equipamentos, instrumentos de pesquisa, vídeos, apresentações em computador e materiais representativos da mineração, cujo principal foco, embo- ra não-exclusivo, seria a época colonial. Pesquisas para formação desse acervo teriam grande potencial de abrir corações e mentes para novas concepções sobre o papel da indústria de mineração no desenvolvimento do país.

Exposição de rochas e bens minerais da região do Jaraguá Em espaço externo ao acima denominado "centro de memória da história da mineração paulista", 


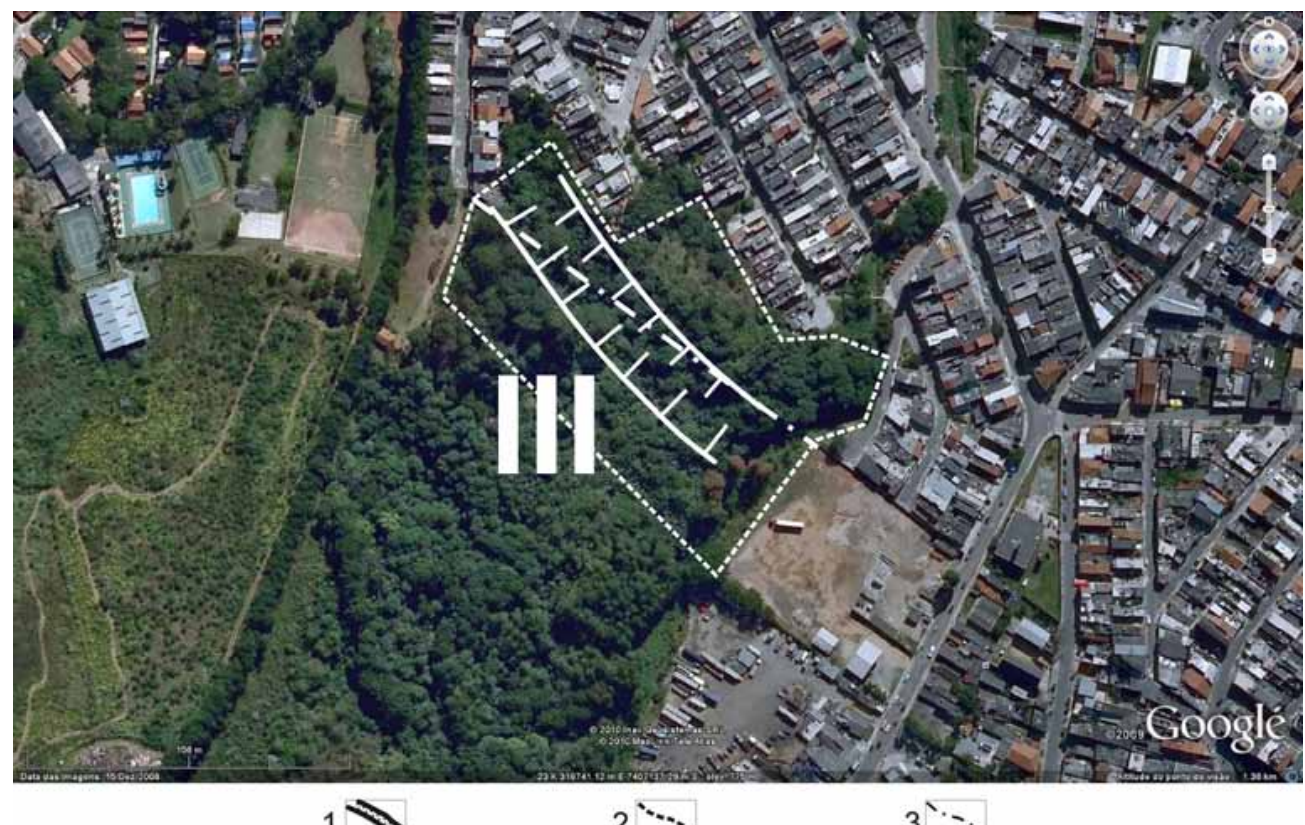

Figura 10 - Situação da Cava III - Morro Doce, em imagem Google Earh. (1) Cava; (2) Proposta de área para medidas de preservação ou tombamento; (3) Limite entre áreas públicas e privadas.
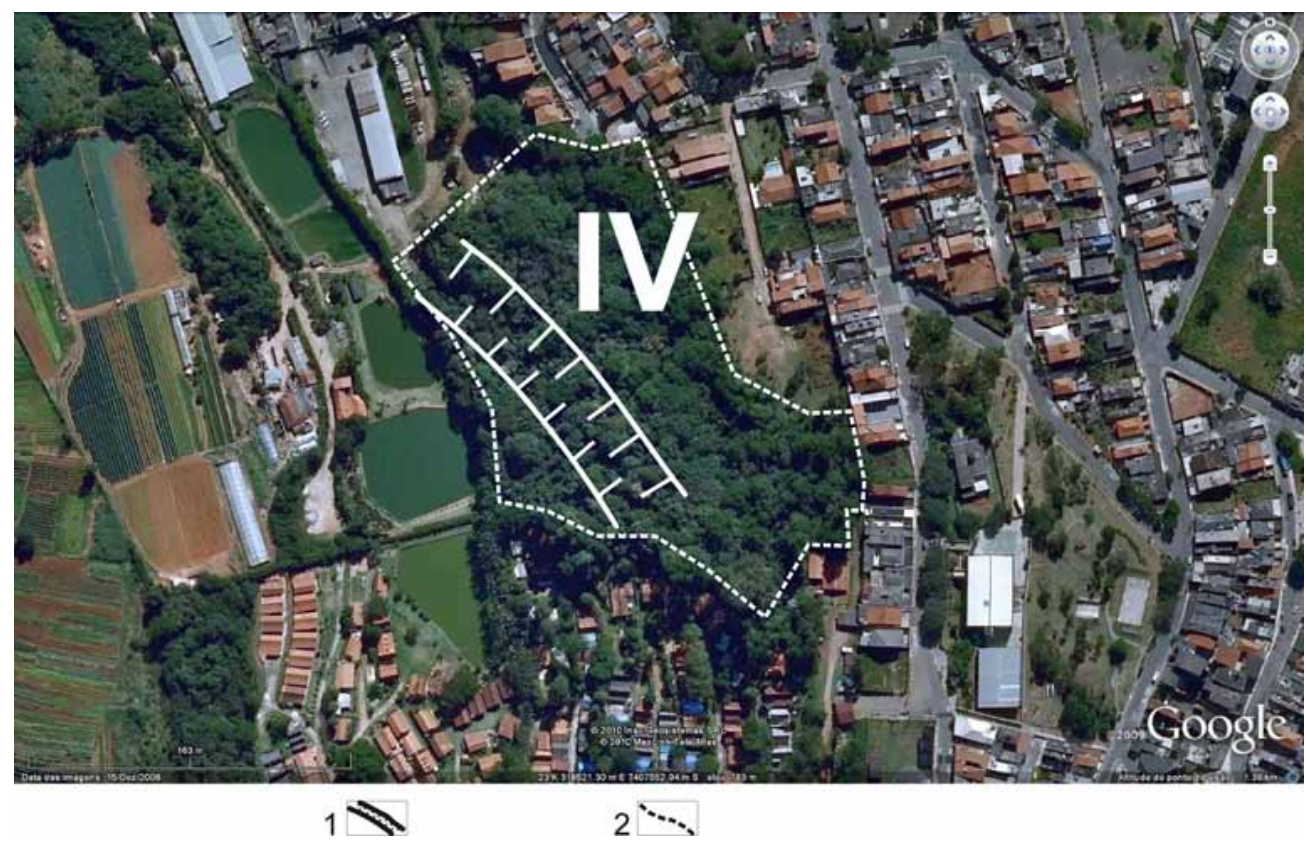

Figura 11 - Situação da Cava IV-Parque Anhangüera, em imagem Google Earh. (1) Cava; (2) Proposta de área para medidas de preservação ou tombamento.

poderá ser montada exposição permanente de amostras de rochas, minérios e minerais da região do Jaraguá e arredores. Empresas do setor mineral que operam pedreiras e outros empreendimentos locais podem fornecer bens obsoletos e amostras grandes para a exposição. Um exemplo é o Parque das Lavras, na cidade de Salto (SP), que organizou, com apoio da indústria de mineração local, bela exposição de diversos tipos de granito do Batólito de Itu. Cada coluna sustenta uma amostra de rocha ornamental extraída da região (Fig. 12).

Roteiros de visita aos sítios históricos A divulgação organizada de dados e conceitos técnico-científicos na área das cavas depende de roteiros de visita, com auxílio de monitores e estudantes das escolas locais. No caso da Cava II - Jardim Britânia, pela necessidade imperiosa de proteger a edificação escolar do desabamento causado por movimentos lentos e graduais dos 

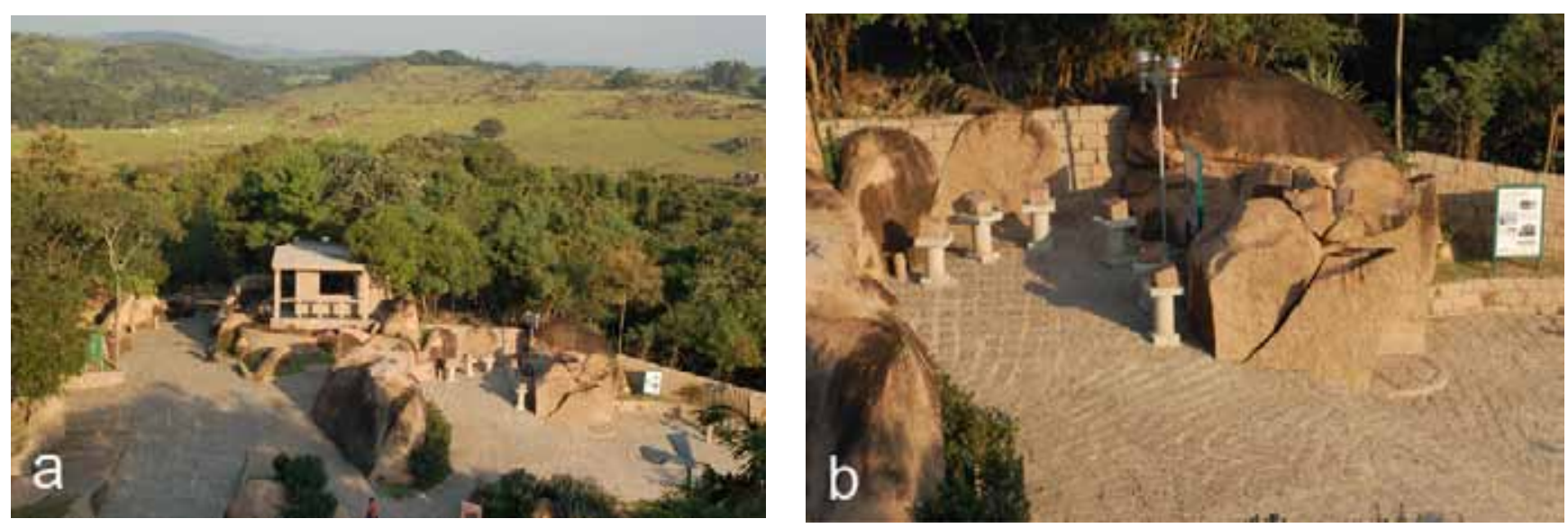

Figura 12 - O Parque das Lavras, circundado por notável campo de matacões (a) é exemplo de exposição permanente de amostras de rochas extraídas em Salto e Itu; em (b) observam-se blocos de rocha polida, colocados sobre pedestais, que correspondem aos tipos comerciais da região.

taludes - e que podem se intensificar com o tempo - é viável pensar em um modesto viaduto que mantenha o acesso à escola, no ponto de conexão, do alto dos taludes. Isso permitirá livre trânsito de pedestres e reafeiçoará a cava. Obras de engenharia sob competente orientação profissional ajudarão a recuperar o padrão anterior e, com apoio de levantamentos geofísicos de detalhe, localizar as galerias de pesquisa construídas no passado e que hoje estão escondidas sob o aterro.

\section{DISCUSSÃO}

Estratégias de geoconservação Todo trabalho de geoconservação requer a avaliação do patrimônio geológico, a fim de fornecer bases para gestão territorial, especialmente em zonas dotadas de notável geodiversidade. Uma vez disponível um inventário, tal como o descrito neste artigo, pode-se definir legislação que proteja os locais de interesse. A formulação de medidas eficazes de geoconservação depende de se dispor de informações detalhadas sobre os sítios considerados e de um quadro jurídico adaptado a tais necessidades (Carcavilla et al. 2007). Na Espanha, a lei de Patrimônio Natural e Biodiversidade (Lei 42/2007, de 13 de dezembro) foi pioneira, por introduzir na legislação daquele país os conceitos de Geodiversidade e de Patrimônio Geológico, e ao estabelecer a necessidade de se trabalhar em prol de sua conservação (FernándezMartínez 2010). O mesmo documento legal atribui às administrações públicas a responsabilidade de gerar conhecimentos e proteger o Patrimônio Geológico.

A pesquisa na área do Morro Doce mostrou várias facetas do indispensável papel do poder público nas iniciativas de geoconservação. Cabe aos órgãos de pesquisa e aos organismos ligados ao governo realizar a etapa de inventário e, com base nos dados e informações recolhidos, encaminhar medidas que subsidiem a legislação. Os resultados expostos incluíram a elaboração de propostas concretas que ajudarão a viabilizar a geoconservação e, posteriormente, a estabelecer estratégias de geodivulgação; isso inclui diferentes alternati- vas de aproveitamento didático das cavas e de fomento ao geoturismo local.

Efeitos práticos do aproveitamento das cavas Quando (ou enquanto) não são estabelecidos limites rígidos e estáveis, a expansão urbana explora intensivamente todo o espaço disponível. São Paulo é caso típico. Pode-se fazer uma analogia com a mineração, porque os lugares, assim como os minérios, também podem chegar à exaustão, sem possibilidade de se regenerar. A finalidade da mineração (Diamond 2006) é:

\begin{abstract}
“(...) explorar recursos que não se renovam com o tempo, e, portanto, esgotá-los. Como o ouro no solo não gera mais ouro e assim não é preciso levar em conta suas taxas de renovação, os garimpeiros extraem ouro de um filão do modo mais rápido e econômico possível, até esse filão se exaurir. A mineração difere da exploração de recursos renováveis - como as florestas, os peixes e o solo - que se regeneram através de reprodução biológica ou formação de solo. (Diamond 2006, p. 453)".
\end{abstract}

Caso sejam efetivamente preservadas e protegidas por legislação específica e por medidas e decisões de órgãos públicos, tanto em nível federal, como estadual e municipal, as cavas comporão um pequeno, porém importante sítio capaz de fomentar atividades na linha moderna do turismo educacional. A região ainda pode estar na mira de empresas de mineração; estava quase inteiramente requerida, junto ao DNPM, para pesquisa de ouro nos anos 1980; em janeiro de 2010 constam requerimentos para ouro, sob titularidade de Cia. Melhoramentos de São Paulo. A implantação de um centro de memória da mineração ajudará a ilustrar em que consistem essas atividades e qual sua importância para a sociedade.

Caso eventuais pesquisas geológicas indiquem a viabilidade da retomada da mineração subterrânea na região, a existência de um centro de turismo e educação ambiental também ajudará a conciliar a explotação com 
a conscientização dos moradores, abrindo espaço para empreendimentos condizentes com as normas ambientais em vigor, que determinam execução organizada e harmônica da atividade mineira, em consonância com preservação ambiental, recuperação da paisagem e solos ou disposição final de rejeitos (Paim 2002).

A nova realidade - caso seja bem-sucedida -, será absolutamente contrastante com a situação atual: nessa parte da cidade vive população numerosa, sem qualquer acesso a bens culturais. A esmagadora maioria dos moradores sequer imagina que sob seus pés existem rochas e recursos que contribuíram para o desenvolvimento da aglomeração urbana de São Paulo, em tempos tão remotos. $\mathrm{O}$ centro de memória ajudará a resgatar auto-estima e ajudá-los a valorizar o pedaço de chão onde vivem.

Assinalamos que medidas de preservação, como as aqui propostas, podem deter aquilo que se convencionou chamar "normalidade deslizante". A expressão se refere a tendências lentas que se escondem por detrás de flutuações que dificultam perceber deterioração que acontece "aos poucos" (Diamond 2006). Isso pode afetar uma região, um bem cultural ou até mesmo um ambiente econômico:

\begin{abstract}
“(...) é difícil reconhecer que cada ano sucessivo está em média ligeiramente pior do que o anterior, de modo que o padrão básico daquilo que constitui a normalidade muda gradual e imperceptivelmente. Pode demorar algumas décadas de leves mudanças anuais até que as pessoas se dêem conta, com surpresa, de que as condições costumavam ser muito melhores algumas décadas antes e que aquilo que se considera normal hoje em dia é uma deterioração daquilo que era normal anteriormente. (Diamond 2006, p. 508509)".
\end{abstract}

A citada ideia de "normalidade deslizante" leva-nos a um triste exemplo: caso um viajante beminformado, ou um grupo de estudiosos, em trânsito pela Rodovia Anhangüera, decidam parar para observar ao longe a Cava II - Jardim Britânia, concluirão ser impossível fazê-lo. Nem ao menos é permitido parar hoje na rodovia. A normalidade "deslizante" não permite que as pessoas vislumbrem, estacionadas ou em baixa velocidade, a escavação histórica... Desde 2008-2009, guard-rails impedem acesso à ampla área terraplenada, adjacente à estrada, na pista interior-capital. O grande espaço lateral livre se tornou inútil, porque inacessível, em defesa da "segurança do tráfego".

CONSIDERAÇÕES FINAIS As escavações da região do Jaraguá, que remontam à época colonial, possuem traçado linear em mapas, sendo formadas por trechos de terreno ocupados por vegetação. São alinhadas aproximadamente segundo a direção N40-50W; suas bordas são dadas por taludes abruptos, escavados em rocha decomposta. Desconhecem-se mapas recentes, além daqueles executados nos anos 1980. Levantamentos geológicos de detalhe poderiam identificar outros vestí- gios nos arredores. Não obstante, o conjunto conhecido constitui significativo fragmento da mineração colonial.

Nas últimas três décadas, a expansão urbana e a abertura de rodovias avançou com grande vigor sobre os vestígios da mineração na região do Jaraguá. A atuação mais decisiva foi do próprio Estado, que aprovou execução de obras que acabaram por descaracterizar uma parte das feições preservadas durante quatro séculos. Foram identificadas e georreferenciadas quatro ocorrências, referidas como Cavas I, II, III e IV. Um outro local (Cava V) não foi identificado. Uma das cavas (Cava II) está parcialmente descaracterizada, devido a aterramento do terreno para construção de escola pública e lançamento de entulho pela população local. Isso não impede que ações sejam tomadas pelo Poder Público para sua proteção. As demais estão bem preservadas, em especial as Cavas III e IV, passíveis de tombamento para futura implantação de parques públicos.

A partir desses elementos, é possível fazer recomendações às autoridades competentes:

1- Avaliar concretamente o tombamento das áreas das Cavas I, II, III e IV e realizar entendimentos para desenvolver programas que culminem na implantação de sítio integrado de divulgação científica ou até mesmo um centro educacional de interesse público abrangendo o conjunto das cavas.

2- Apoiar o manifesto interesse dos proprietários de parcela expressiva de uma das áreas (pois o restante pertence ao município), no sentido de preservar a área aqui denominada "Cava III - Morro Doce" e estender tal preocupação às demais.

3- Implementar propostas de ação para uso das cavas com finalidades educativas, tendo em vista algumas opções já delineadas:

a- Implantação de centro de história da mineração paulista. b- Montagem de exposição permanente com rochas, minérios e minerais da região do Jaraguá e arredores. c- Elaboração de roteiros de visita aos sítios históricos.

Em complemento às conclusões acima, um dado relevante: em 15 de março de 2011 o conteúdo do artigo foi convertido em palestra para o Conselho Municipal de Preservação do Patrimônio Histórico, Cultural e Ambiental da Cidade de São Paulo (CONPRESP). $\mathrm{Na}$ mesma reunião, as autoridades deliberaram favoravelmente à abertura do processo de tombamento das áreas. Conclui-se que, hoje, diferentemente do cenário vivido nas últimas três décadas, de ameaças reais de perda de patrimônio, a resposta à pergunta-título do artigo é altamente positiva: em lugar do abandono, ainda há muito para se preservar das Cavas Históricas do Jaraguá. A melhor parte da história, espera-se, ainda está por ser contada.

Agradecimentos Os autores agradecem a contribuição, no decorrer da pesquisa, dos Srs(as).: Cristina Maffra (MPF); Helio Shimada (IG-SMA); José Manoel Cardoso (proprietário de área); Luiz Antonio Chieregati (CPRM); Sandra Mami Amenomori (MPF) e Virgínio Mantesso Neto (Consultor). 


\section{Referências}

Almeida F.F.M.de, Brito-Neves B.B.de, Carneiro C.D.R. 2000. Origin and evolution of the South-American Platform. Earth Science Reviews, 50(1-2):77-111.

Almeida F.F.M.de, Carneiro C.D.R. 1995. Geleiras no Brasil e os parques naturais de Salto e Itu. Ciência Hoje, 19(112):24-31.

Carcavilla L., Durán J.J., García-Cortés Á., López-Martínez J. 2009. Geological Heritage and Geoconservation in Spain: past, present, and future. Springer, Geoheritage, 1:75-91. Publ. Online 21.10.2009. DOI 10.1007/ s12371-009-0006-9. URL: http:/www.springerlink. com/content/724u06m0rv433r57/fulltext.pdf. Acesso 2.05.2011.

Carcavilla L., López-Martínez J., Durán J.J. 2007. Patrimonio geológico y geodiversidad: investigación, conservación, gestión y relación con los espacios naturales protegidos. Madrid, Inst. Geol. y Minero de España, Cuadernos del Museo Geominero, (7):360p.

Carneiro C.D.R. 1983. Análise estrutural do Grupo São Roque na faixa entre o Pico do Jaraguá e a Serra dos Cristais, SP. Tese de Doutoramento, São Paulo: Inst. Geoc. USP. $155 \mathrm{p}$.

Carneiro C.D.R. 1996. As cavas antigas de ouro do Jaraguá. Ciência Hoje, 21(125)22. (Crônica).

Carneiro C.D.R. 2002. Cavas de Ouro Históricas do Jaraguá, SP. Os primórdios da mineração no Brasil. In: Carlos Schobbenhaus, Diogenes de Almeida Campos, Emanuel Teixeira de Queiroz, Manfredo Winge, Mylène Luíza Cunha Berbert-Born. (eds.) Sítios Geológicos e Paleontológicos do Brasil. Brasília: BRASIL. Depto. Nac. Prod. Mineral (DNPM) / Serv. Geol. Brasil (CPRM). Comissão Brasileira de Sítios Geológicos e Paleobiológicos (SIGEP), p. 511-516.

Carneiro C.D.R., Hasui Y., Nagata N., Lima M.O.de. 1985. Padrões de superposição de estruturas do Grupo São Roque na faixa Jaraguá-Cristais (SP). Rev. Bras. Geoc., 15(2):116-130.

Carneiro C.D.R., Herrmann H. 1994a. Fim do Pró-Minério ... o que virá depois? Parte I: Brasil Mineral, (120):46-48.

Carneiro C.D.R., Herrmann H. 1994b. Fim do Pró-Minério ... o que virá depois? Parte 2: Brasil Mineral, (121):30-33.

Carneiro C.D.R., Santos L.F.dos, Silva J.R.B.da. 2010. Cavas de Ouro Históricas do Jaraguá. Identificação de áreas para preservação ou tombamento, bairros Morro Doce e Jardim Britânia, São Paulo, SP. Campinas: Univ. Est. Campinas, 29p. (Rel. técn. ao Ministério Público Federal, Procuradoria da República no Est. S.Paulo, inédito).

Coutinho J.M.V. 1980. Carta Geológica da região metropolitana da Grande São Paulo, escala 1:100.000. São Paulo: EMPLASA (2 folhas).

Diamond J. 2006. Colapso: como as sociedades escolhem o fracasso ou o sucesso. 4 ed. Trad. A. Raposo. Rio de Janeiro: Record, 683p.

Fernández-Martínez E., Fuertes Gutiérrez I., González Gutiérrez R.B., Redondo Vega J.M., Alonso Herrero E. 2010. Lugares de interés geológico en la Provincia de Palencia (noroeste de España): un inventario y varios casos de estudio. In: Florido P., Rábano I. (eds.) Una visión multidisciplinar del patrimonio geológico y minero. Madrid, Inst. Geol. y Minero de España, Cuadernos del Museo Geominero, (12):97-107.

Figueiredo M.C.H., Bergman M., Penalva F., Tassinari C.C.G. 1982. Ocorrência de "pillow lavas"no Grupo São Roque, Estado de São Paulo. Ciências da Terra, (2):6-8.

Hasui Y., Penalva F., Hennies W.T. 1969. Geologia do Grupo São Roque. In: SBG, Congr. Bras. Geol., 23, Salvador, Anais, p. 101-134.

Heilbron M., Pedrosa-Soares A.C., Silva L.C., Campos Neto M.C., Trouw R.A.J. 2004. A Evolução Tectônica da Província Mantiqueira. In: Mantesso-Neto V., Bartorelli A., Carneiro C.D.R., Brito-Neves B.B. de. (orgs.) Geologia do Continente Sul-Americano: Evolução da obra de Fernando Flávio Marques de Almeida. São Paulo: Beca. p. 203-234. (Cap. XIII).

Instituto de Pesquisas Tecnológicas do Estado de São Paulo (IPT). 1981. Mapa de jazidas e ocorrências minerais do Estado de São Paulo, escala 1:500.000. São Paulo. 3 v. (IPT. Monografias 4, Publ. 1171).

Knecht T. 1950. Ocorrências minerais do Estado de São Paulo. São Paulo, Inst. Geogr. e Geol. 2v.

Mantesso Neto V., Bartorelli A., Carneiro C.D.R., BritoNeves B.B.de. (orgs.) 2004. Geologia do Continente Sul-Americano: Evolução da obra de Fernando Flávio Marques de Almeida. São Paulo: Ed. Beca. 673p.

Martins R.B., Brito O.E.A.de, Falzoni R. 1989. História da mineração no Brasil: History of mining in Brazil. São Paulo: Emp. das Artes Projetos e Edições Artisticas.

Paim P.S.G. 2002. Minas do Camaquã, RS. Marco da história da mineração de cobre no Brasil. In: Schobbenhaus C., Almeida Campos D. de, Queiroz E.T.de, Winge M., Berbert-Born M.L.C. (eds.) Sítios Geológicos e Paleontológicos do Brasil. Brasília: BRASIL. Departamento Nacional de Produção Mineral (DNPM)/Serviço Geológico do Brasil (CPRM). Comissão Brasileira de Sítios Geológicos e Paleobiológicos (SIGEP), p. 501-510.

Projeto Tesouros do Brasil. 2005. Escavações do Morro Doce. In: Projeto Tesouros do Brasil. 2005. Tesouros do Brasil. São Paulo: Fiat Automóveis. p. 28-29. Disponível em http://www.fiat.com.br/mundo-fiat/sustentabilidade/ cultura/tesouros-do-brasil.jsp. Acesso 15.02.2010.

Tassinari C.C.G. 2010. Lavas almofadadas de Pirapora do Bom Jesus, SP. Brasília: BRASIL. Departamento Nacional de Produção Mineral (DNPM) / Serviço Geológico do Brasil (CPRM). Comissão Brasileira de Sítios Geológicos e Paleobiológicos (SIGEP). (Proposta de sítio geológico ou paleobiológico do Brasil). Disponível em: http://sigep.cprm.gov.br/propostas/Lavas_almofadadas_ Pirapora_Bom_Jesus_SP.htm. Acesso 3.04.2011.

Tassinari C.C.G., Munhá J.M.U., Ribeiro A., Correia C.T. 2001. Neoproterozoic oceans in the Ribeira Belt (southeastern Brazil): the Pirapora do Bom Jesus ophiolitic complex. Episodes, 24(4):245-251.

Manuscrito ID 17092 Submetido em 24 de março de 2010 Aceito em 26 de maio de 2011 